\title{
KONSEP DIRI WARIA \\ (FENOMENA WARIA DI AKADEMI PARIWISATA MAKASSAR)
}

\author{
Novita Ashari \\ Institut Agama Islam Negeri Parepare \\ novitaashari@iainpare.ac.id
}

\begin{abstract}
This study aims to describe the self-concept of the transgender and the process of forming the self-concept of the transgender. The data analysis of the research results was carried out qualitatively. The approach used is a phenomenological approach, where the subjects studied are transgender women who study at the Makassar Tourism Academy. The results of the study prove that Subject $1(N N)$ and subject $2(O P)$ have a negative self-concept because they are unable to position themselves as a whole, being male or female. After all, they can play two genders at once, confusing gender, while 3 (ED) has a positive self-concept because the subject is positive about him.
\end{abstract}

Keywords : self-concept, transgender

\begin{abstract}
ABSTRAK
Penelitian ini bertujuan untuk mendiskripsikan konsep diri kaum waria dan proses pembentukan konsep diri kaum waria. Analisis data hasil penelitian dilakukan secara kualitatif. Pendekatan yang digunakan adalah pendekatan fenomenologi, dimana subjek yang diteliti adalah waria yang kuliah di Akademi Pariwisata Makassar. Hasil penelitian membuktikan bahwa Subjek $1(\mathrm{NN})$ dan subjek 2 (OP) memiliki konsep diri yang cenderung negatif dikarenakan belum mampu memposisikan diri seutuhnya menjadi laki-laki atau perempuan karena mampu memerankan dua jenis kelamin sekaligus dalam kehidupannya sehingga mengalami kebingungan identitas jenis kelamin, sementara subjek 3 (ED) memiliki konsep diri yang cenderung positif dikarenakan penilaian positif terhadap dirinya.
\end{abstract}

Kata Kunci : konsep diri, waria

\section{PENDAHULUAN}

Manusia merupakan makhluk sosial dimana saling membutuhkan satu sama lain. Pada zaman modern sekarang ini yang serba kompleks sebagai produk dari kemajuan teknologi banyak memunculkan masalah yang akan membawa dampak negatif. Masalah sosial tersebut terjadi karena adanya penyimpangan terhadap konsep masyarakat ideal. Salah satu jenis manusia yang sering memiliki penyimpangan konsep ideal adalah waria.

Pengertian waria (wanita-pria), atau dalam bahasa sehari-hari dikenal sebagai "bencong" adalah istilah bagi laki-laki yang menyerupai perilaku wanita. Secara istilah, waria adalah laki-laki yang berbusana dan bertingkah laku sebagaimana layaknya wanita. Istilah ini awalnya muncul dari masyarakat Jawa 
Timur pada tahun 1980-an. Secara fisiologis, waria sebenarnya adalah pria. Namun pria (waria) ini mengidentifikasikan dirinya menjadi seorang wanita dalam tingkah laku keseharian. Seperti dalam penampilan atau dandanan, mereka mengenakan busana dan aksesori seperti wanita. Demikian pula dalam perilaku sehari-hari, mereka merasa dirinya sebagai seorang wanita yang memiliki sifat lemah lembut (Faidah \& Abdullah, 2013).

Permasalahan waria menyangkut moral dan perilaku yang dianggap tidak wajar, karena secara normatif tidak ada kelamin ketiga di antara laki-laki dan perempuan. Tercermin dari penerimaan masyarakat terhadap pria transgender yang sebatas formalitas. Sehingga memunculkan pertanyaan, bagaimanakah kaum transgender mendapatkan kepuasan hidup di tengah diskriminasi sosial dan kebingungan Kepuasan hidup pria transgender (waria) sehingga dapat menemukan apa yang menjadi sumber kepuasan hidupnya? (Ruhghea, S., dkk, 2014).

Hasil penelitian Alfaris (2018) menjelaskan bahwa waria bisa berkembang dalam sebuah komunitas karena memiliki eksistensi diri. Eksistensi diri waria memiliki proses konsep yang cukup luas di mana jiwa dan raganya terbentuk melalui imajinasi, emosi, kognisi, dan aksi. Dapat dikatakan waria merupakan sosok manusia ketiga dari absolut gender dan seksualitasnya yang terbentuk melalui tekanan dan sosialisasi pada umumnya, kemudian diinternalisasi ke dalam tindakan secara normal, karena orientasi seksualitasnya berjalan normal sesuai dengan gender yang dipilihnya.

Kemudian, hasil penelitian Elizabeth membenarkan bahwa seorang waria adalah Individu yang memiliki fisik pria tetapi psikisnya wanita yang diperoleh sejak lahir. Mereka terdiri atas dua golongan yaitu interseksualita dengan organ seksual pria tetapi juga mempunyai hormon wanita, dan transeksualisme sebagai seseorang yang mempunyai fisik pria tetapi psikis wanita. Selain itu, hasil penelitian juga menguatkan pendapat para ahli di bidang kelainan seks bahwa kaum waria memiliki hasrat hubungan seks yang sangat tinggi dengan laki-laki. Untuk memenuhi hasrat seks itu, mereka sebagian besar melakukannya dengan cara "turun ke jalan". Hubungan seks secara tetap dengan pacar dan ada pula dengan cara membayar pria yang diinginkan dan bersedia melayaninya (Barmawi, dkk., 2016).

Namun, agak sedikit berbeda dengan waria yang ada di Kota Makassar, khususnya di Akademi Pariwisata 
Makassar. Pada umumnya mahasiswa yang kuliah di Akademi Pariwisata Makassar berjenis kelamin perempuan, dan cukup sedikit yang berjenis kelamin laki-laki. Hal tersebut dikarenakan jurusan yang terdapat di Akademi Pariwisata ini sangat berhubungan erat dengan pekerjaan perempuan. Sehingga kebanyakan laki-laki yang kuliah di Akademi Pariwisata merupakan waria. Sebagian dari mereka masih kuliah dengan menggunakan pakaian layaknya pria karena mereka belum mempunyai keberanian menyatakan diri sebagai waria dengan menggunakan rok. Hal ini disebabkan karena menurut mereka, masyarakat di Indonesia masih sangat dipengaruhi oleh norma-norma sopan santun yang berlaku serta mereka tidak ingin masyarakat mencemooh dan memandang hina diri mereka secara terang-terangan.

Waria akan mencari teman atau populasi yang keadaannya serupa dengan diri mereka agar mereka dapat diterima dan dihargai sebagai individu yang utuh, sebagaimana layaknya individu yang normal. Selanjutnya timbul masalah lain, yaitu pemenuhan kehidupan sehari-hari, sementara tidak semua waria memiliki bakat dan keterampilan yang memadai untuk bertahan hidup, sehingga cara yang mereka lakukan adalah menjajakan diri dalam dunia pelacuran. Pandangan masyarakat yang sering ditujukan pada waria adalah bahwa waria identik dengan prostitusi. Ironisnya, pada saat yang lain diam-diam masyarakat juga berminat pada jasa pelayanan waria (Prasetya, 2020).

"Begini mi saya, mau diterima ya sudah. Saya nda mau dibilang munafik. Kalau ada yang mau menerima kekuranganku ya sudah mi kuhargaiki juga”.

Subjek menerima dirinya apa adanya begitupun juga orang lain. Apabila ada individu lain yang mampu menerima dirinya, maka ia sangat menghargai hal tersebut. Hal tersebut sesuai dengan hasil penelitian yang dilakukan Ibrahim, dkk. (2015) yang menjelaskan bahwa identitas waria terbentuk karena dengan menjadi waria merupakan cara yang paling tepat untuk memperkenalkan diri mereka kepada lingkungan sosialnya. Dalam hal ini, pamor menjadi waria merupakan media yang paling ampuh dalam menyampaikan pesan (isi hati yang terpendam) untuk diketahui orang lain secara sengaja. Di mana seserang yang menjadi waria akan terbebas dari pekerjaan-pekerjaan yang sifatnya kasar dan menguras tenaga, serta sebagai ajang didalam meniti karier yang lebih baik. Upaya untuk memahami diri sendiri didapat dari proses identifikasi diri dengan orang lain. 
Konsep diri bukan merupakan faktor yang dibawa sejak lahir, tetapi merupakan faktor yang dipelajari dan terbentuk dari pengalaman individu dalam hubungannya dengan orang lain. Dalam berinteraksi setiap individu akan menerima tanggapan-tanggapan yang diberikan dan dijadikan cermin bagi individu untuk menilai dan memandang dirinya sendiri (Faidah \& Abdullah, 2013).

\section{METODE PENELITIAN}

\section{Desain Penelitian}

Analisis data hasil penelitian dilakukan secara kualitatif. Pendekatan yang digunakan adalah pendekatan fenomenologi, dimana subjek yang diteliti adalah waria yang kuliah di Akademi Pariwisata Makassar. Hal yang diteliti adalah menyangkut konsep diri waria yang cenderung negatif. Selanjutnya pengumpulan data dilakukan dengan teknik observasi dan wawancara. Observasi dilakukan pada saat melakukan wawancara. Proses wawancaranya adalah dengan melakukan tanya jawab sambil bertatap muka antara pewawancara dengan subjek atau individu yang diwawancarai.

\section{Batasan Istilah}

Waria adalah laki-laki yang bertingkah laku dan berpenampilan menyerupai wanita (feminim), beragama, dan berstatus mahasiswa. Konsep diri yang dimaksud yaitu persepsi tentang diri seorang waria yang memiliki latar belakang pendidikan yang baik seperti misalnya waria yang berstatus mahasiswa di Perguruan Tinggi.

\section{Kriteria Subjek}

Kriteria subjek dalam penelitian ini adalah laki-laki yang berpenampilan seperti perempuan yang masing-masing berasal dari latar belakang keluarga berbeda yang digambarkan sebagai berikut: berusia 18-25 tahun, laki-laki yang telah dikategorikan sebagai waria dan mahasiswa yang kuliah di Akademi Pariwisata Makassar (AKPAR).

\section{Teknik Pengumpulan Data}

Observasi partisipan digunakan observer untuk penelitian yang bersifat eksploratif. Observasi partisipan terjadi jika orang yang mengadakan observasi turut ambil bagian dalam kehidupan observer. Lebih spesifik lagi observer turut berpartisipasi secara fungsional. Alasan peneliti melakukan observasi adalah untuk menyajikan gambaran realistik perilaku atau kejadian, untuk menjawab pertanyaan, untuk membantu mengerti perilaku manusia, dan untuk evaluasi yaitu melakukan pengukuran terhadap aspek 
tertentu melakukan umpan balik terhadap pengukuran tersebut.

Wawancara adalah metode pengumpulan data dengan jalan tanya jawab sepihak yang dikerjakan dengan sistematik dan berlandaskan kepada tujuan penyelidikan (Hadi; Rahayu \& Ardani, 2004). Wawancara mendalam adalah proses memperoleh keterangan dengan tujuan agar peneliti dalam melakukan penelitian dapat melakukan tanya jawab sambil bertatap muka antara pewawancara dengan subjek atau orang yang diwawancarai, dengan menggunakan guide interview, dimana pewawancara dan subjek terlibat dalam kehidupan sosial yang relatif lama. Hal tersebut dimaksudkan agar subjek dapat diwawancarai secara lebih mendalam dan didapatkan hasil yang sesuai.

\section{HASIL DAN PEMBAHASAN}

\section{Subjek Pertama}

Terdapat beberapa hal yang menyebabkan subjek penelitian menjadi waria, ditambah dengan kepribadian yang ada dalam diri subjek yang membentuk suatu dinamika konsep diri yang kemudian mampu mengarahkan subjek pada konsep diri positif maupun negatif.

"Wujudkuji laki-laki tapi saya perempuan"
Pandangan seseorang tentang diri $\mathrm{NN}$ yang baik maupun buruk dapat diterima NN dengan senang hati dan terbukti pada saat $\mathrm{NN}$ dicemooh tentang status diri NN sebagai waria, NN selalu menanggapinya dengan santai dan NN selalu mengatakan kepada orang lain bahwa saya sangat menghargai orang yang menerima saya apa adanya dan ini juga bukan semata-mata karena keinginannya namun sudah menjadi kehendak dari Yang Maha Kuasa.

"Saya begini bukan saya yang mau tapi Tuhan yang kasi beginika"

Faktor yang dapat mempengaruhi pembentukan konsep diri seseorang adalah citra tubuh, ketrampilan berbahasa, orang tua dan teman sebaya. Lebih lanjut dijelaskan bahwa sumber-sumber yang mempengaruhi perkembangan konsep diri seseorang adalah peranan citra fisik, peranan seksual, peranan perilaku orang tua dan peranan faktor sosial. Hal ini membuktikan bahwa faktor lingkungan yang terdiri dari orang tua, teman bergaul, masyarakat dan penilaian tentang ciri fisik dapat membentuk konsep diri pada diri seseorang (Widiarti, 2017).

Kecenderungan bertingkah laku feminim ditunjukkan dari gaya bicara yang kemayu, cara duduk yang feminim yaitu dengan merapatkan kedua kaki dan menyilangkan kaki, selain itu pakaian 
seperti celana yang sangat pendek dan ketat (Alfaris, 2018). Ciri yang lain adalah pada saat bertemu dengan laki-laki khususnya dengan laki-laki yang berbadan kekar, NN akan menatapnya dengan malumalu dan menunjukkan ketertarikannya pada laki-laki tersebut.

"Kalo saya lebih suka bergaul sama cewek, karena saya sama kayak mereka, sensitif."

Keluarga dan orang tua memberikan gambaran yang sedikit kurang baik terhadap NN, namun teman bergaul dan masyarakat memberi gambaran yang baik tentang diri NN. Sehingga dalam diri NN tercermin bahwa belum mampu memposisikan diri seutuhnya menjadi laki-laki atau perempuan karena $\mathrm{NN}$ mampu memerankan dua jenis kelamin sekaligus dalam kehidupannya sehingga NN mengalami kebinggungan identitas jenis kelamin yang menyebabkan gambaran tentang diri NN negatif.

Dari penjelasan diatas terlihat bahwa ada beberapa kebutuhan dalam diri NN. Kebutuhan tersebut dapat dikaji dengan teori kebutuhannya Maslow yang menyatakan bahwa kebutuhan yang harus dipenuhi agar manusia dapat berkembang dengan baik dibagi menjadi tujuh tingkatan. Secara ringkas ketujuh tingkatan kebutuhan menurut Maslow adalah kebutuhan biologis, kebutuhan akan rasa aman, kebutuhan akan cinta kasih dan rasa memiliki, kebutuhan akan penghargaan, kebutuhan untuk tahu, kebutuhan akan keindahan dan kebutuhan akan kebebasan bertindak (Noor, 2019).

Maslow membedakan motif manusia berdasarkan taraf kebutuhannya, mulai dari kebutuhan biologis yang dibawa manusia sejak lahir sampai dengan kebutuhan psikologis yang kompleks. Menurut Maslow suatu motif akan menguasai tingkah laku seseorang bila motif yang berada dibawahnya sudah terpenuhi. Tingkah laku manusia mulamula dikuasai oleh motif yang paling rendah, yaitu motif psikologis seperti misalnya motif lapar, haus, seks dan seterusnya. Baru setelah motif tersebut terpenuhi (kebutuhannya) motif diatasnya mulai menguasai, begitu seterusnya sampai dengan motif paling tinggi yaitu motif aktualisasi diri (Noor, 2019).

NN sebagai seorang waria juga memiliki kebutuhan yang sama dengan manusia pada umumnya. Sebagai seorang manusia NN menginginkan kebutuhan biologisnya terpenuhi, meskipun kebutuhan biologis yaitu kebutuhan seks harus disalurkan dengan sesama jenis dan dilakukan melalui oral (mulut) dan anal (anus). NN juga mempunyai kebutuhan akan rasa aman yaitu NN menginginkan supaya keluarga maupun orang tua tidak 
melarang $\mathrm{NN}$ berperan dan berperilaku seperti perempuan dan $\mathrm{NN}$ juga berharap supaya masyarakat tidak mencemooh, mencaci dan mengucilkan keadaan dirinya yang hidup sebagai seorang waria. Selain itu NN ingin mendapatkan kasih sayang dari orang lain yaitu dari keluarga, teman bergaul dan masyarakat. Kecaman maupun penolakan tidak akan ada apabila adanya suatu penghargaan dan pengakuan dari masyarakat terhadap keberadaannya.

\section{Subjek Kedua OP}

Beberapa faktor yang menyebabkan OP menjadi seorang waria dan kepribadian yang terbentuk dalam diri OP cenderung bersifat menetap. Kepribadian OP merupakan salah satu faktor yang mempengaruhi konsep diri OP. Kepribadian dalam diri OP juga menjadi suatu patokan saat OP mendapat suatu penilaian dari keluarga, teman bergaul dan masyarakat sekitar tempat tinggalnya. Pandangan seseorang tentang diri OP baik positif maupun negatif berusaha diterima oleh OP dengan besar hati dan terbukti pada saat OP dicemooh tentang status diri OP sebagai waria, OP selalu menanggapinya dengan santai dan menghargai apa adanya dan ini juga bukan semata-mata karena keinginannya namun sudah menjadi kehendak dari Yang Maha Kuasa. Konsep diri yang terbentuk dalam diri OP tidak hanya diukur dari kepribadiannya saja melainkan ada juga faktor-faktor lain yang dapat membentuknya yaitu adanya faktor-faktor yang mempengaruhi perkembangan konsep diri dan dimensi konsep diri.

Damarhadi, S., dkk (2020) menyatakan bahwa konsep diri merupakan evaluasi individu mengenai diri sendiri, penilaian atau penafsiran mengenai diri sendiri oleh individu yang bersangkutan. Saputri dan Moordiningsih (2016) menambahkan bahwa konsep diri adalah suatu gambaran campuran dari apa yang kita pikirkan, orang lain berpendapat mengenai diri kita, dan seperti apa diri kita yang kita inginkan.

Pernyataan tersebut bisa dilihat dari hasil penelitian pada subyek kedua yang menjelaskan bahwa konsep diri yang ada pada diri OP dipengaruhi oleh citra diri, keluarga dan orang tua, teman bergaul dan masyarakat sekitar OP. Faktor yang dapat mempengaruhi perkembangan konsep diri OP yang pertama adalah citra diri, dimana OP cenderung berperilaku feminim, OP merasa nyaman apabila dirinya dianggap sebagai perempuan, selalu berdandan dan berpenampilan seperti perempuan, namun OP juga mampu berperan sebagai laki-laki terutama saat OP beraktivitas di kampus.

Kecenderungan bertingkah laku feminim ditunjukkan dari gaya bicara yang 
kemayu, cara duduk yang feminin yaitu dengan merapatkan kedua kaki dan menyilangkan kaki, selain itu pakaian seperti celana yang sangat pendek dan ketat. Ciri yang lain adalah pada saat bertemu dengan laki-laki yang disukainya OP akan menatapnya dengan malu-malu dan menunjukkan ketertarikannya pada laki-laki tersebut.

"Jarang berteman sama cowok saya. Mulai dari kecil umur 5 tahun. Sampai sekarang saya kalo ngajak teman ke rumah pasti cewek."

Salah satu faktor yang mempengaruhi perkembangan konsep diri yang adalah keluarga dan orang tua, dimana keluarga dan orang tua merupakan pembentuk konsep diri pada diri OP. Hubungan OP dengan keluarga dan orang tua baik tetapi karena orang tua terlalu sibuk, ditambah dengan saudara yang cukup banyak sehingga kurang perhatian.

"Yah dulu sih karena mungkin orang tua terlau sibuk sehingga gak dihiraukan, begitu."

Pernyataan OP di atas senada dengan hasil penelitian yang dilakukan oleh Faidah dan Abdullah (2013) yakni ada tiga hal yang memicu seseorang menjadi waria, salah satunya adalah bagaimana bentuk pola asuh orang tua. Orang tua yang sangat sibuk dan membiarkan anak laki-laki menggunakan identitas perempuan sejak awal akan sangat mempengaruhi pekembangan konsep diri seseorang. Dimana pada usia dini anak akan sangat mudah menyerap segala kondisi yang ada di sekitarnya dan hal tersebut akan melekat hingga ia dewasa.

Sejak kecil OP sudah terlihat berbeda dengan teman laki-lakinya. OP lebih suka bermain dengan teman perempuan dari pada teman laki-laki. Walaupun demikian, OP tetap memiliki teman laki-laki. Hingga pada akhirnya OP menginjak remaja, karena sudah terbiasa kemayu dan teman-teman disekitarnya juga apabila mengejek OP keseringan akhirnya OP terbiasa dengan hal seperti itu, jadi OP tidak menghiraukannya lagi.

Keluarga dan orang tua memberikan gambaran yang sedikit kurang baik terhadap OP, namun teman bergaul dan masyarakat memberi gambaran yang baik tentang diri OP. Sehingga dalam diri OP tercermin bahwa belum mampu memposisikan diri seutuhnya menjadi laki-laki atau perempuan karena OP mampu memerankan dua jenis kelamin sekaligus dalam kehidupannya sehingga OP mengalami kebinggungan identitas jenis kelamin yang menyebabkan gambaran tentang diri OP negatif.

Dari penjelasan diatas dapat digambarkan secara jelas melalui faktorfaktor yang mempengaruhi konsep diri, 
antara lain salah satunya orang Lain. Jika kita diterima orang lain, dihormati, dan disenangi karena keadaan diri kita, kita akan cenderung bersikap menghormati dan menerima diri kita begitupun sebaliknya. Tidak semua orang lain mempunyai pengaruh yang sama terhadap diri kita. Ada yang paling berpengaruh yaitu orangorang yang paling dekat dengan diri kita (Rahmaningsih \& Martani, 2018)

\section{Subjek Ketiga}

Subjek dengan inisial ED menjadi seorang waria karena berbagai hal. Namun, kepribadian yang terdapat dalam diri subjek cenderung menetap. Kepribadian yang terdapat dalam diri ED juga merupakan bentuk dari suatu benteng karena ED tidak pernah mendapatkan perlakuan yang berupa penolakan dari lingkungan maupun keluarga ED.

"Oh, kalo penolakan sih mba gak ada sama sekali. Kemayuku kan memang udah dari anak-anak. Saya sering main sama teman-teman cewek ku, tidur samasama. Sepupuku juga kebanyakan perempuan, tapi gak taumi juga mba bagaimana prosesnya hingga saya bisa kayak gini. Tapi orang sih di kampung liat saya kayak gini biasa-biasa aja, gak ada namanya penolakan gitu mba ya kan hak kita hidup seperti itu."
Saputri dan Moordinigsih (2016) mengungkapkan beberapa faktor yang mempengaruhi perkembangan konsep diri, yaitu peranan citra fisik, peranan seksual, peranan perilaku orang tua, dan peranan faktor sosial. Konsep diri ED cenderung positif dikarenakan faktor-faktor yang mempengaruhi perkembangan konsep diri ED tidak mengalami kesulitan, misalnya tidak menglalami penolakan.

Faktor pertama yang mempengaruhi konsep diri ED adalah bagaimana peranan citra fisik ED. ED mengaku memiliki perasaan yang sangat peka terhadap perkataan kasar, dengan kata lain perasaan ED sangat sensitif. Oleh sebab itu, ED lebih senang bergaul dengan perempuan karena memiliki banya kesamaan. Sejak kecil ED memiliki teman kebanyakan wanita. Namun, ED berpenampilan tidak seperti perempuan ataupun seperti subjek pertama NN. ED cenderung bersifat jaim ketika berhadapan dengan banyak orang dan tidak terlalu menampakkan sisi "kewanitaannya" kepada laki-laki yang baru dikenalnya. Perilaku feminin ED ditunjukkan dengan tangannya yang gemulai dan perasaannya yang sensitif.

“Ah, lebih dari pada perempuan. Apalagi kalo kata-kata kasar gitu. Ahh, sensetif banget. Tapi yah gimana ya, udahmi de mba" 
Faktor yang kedua adalah peran seksual. Subjek lebih senang menjalin hubungan yang spesial dengan laki-laki. ED pernah mengalami suatu kejadian, dimana ED terbangun dalam keadaan bugil karena tidur bersama sepupu laki-lakinya. Semenjak kejadian itu, subjek ketagihan dan perilaku tersebut berlangsung sampai sekarang. ED telah memiliki teman lakilaki yang spesial atau pacar dalam hidupnya. Bahkan subjek telah bergontaganti pacar. ED merasa kalau pacaran sama cowok itu beda dari yang lain. Dari lubuk hati ED, ada kemauan untuk memiliki perasaan yang dianggap normal, yaitu perempuan. Namun keinginan tersebut tidak ingin direalisasikan pada saat sekarang, semua ada waktunya. Subjek juga ingin memiliki keturunan seperti halnya laki-lakin normal yang lain. Walaupun ED mengaku memiliki jiwa yang sangat perempuan, namun ED memiliki tekad dan kemauan untuk berubah sehingga ED tidak mengalami kebingungan identitas jenis kelamin kedepannya yang menyebabkan gambaran tentang diri ED positif.

"Jujur ya mba yah, kalo saya sih punya memang. Ada sih beberapa. Bagaimana di' mba? Kalo cowok itu kan mungkin beda dari yang lain ya"

Faktor ketiga adalah peranan perilaku orang tua. Lingkungan yang pertama menaggapi perilaku kita adalah lingkungan keluarga, maka dapat dikatakan bahwa keluarga merupakan ajang pertama dalam membentuk konsep diri anak. Ayah ED sudah meninggal sejak ED masih kecil, sehingga tidak ada panutan yang baik dari sosok seorang ayah dari ED. Berhubung karena ED tinggal berjauhan dari ibunya, ED kurang mendapat perhatian dari kedua orang tuanya. ED hanya bertemu ibunya di akhir pekan. ED pernah suatu ketika mendapat nasehat dari ibunya, namun ED hanya mengiyakan apa yang dikatakan ibunya dan tidak dianggap serius. ED memiliki seorang kakak laki-laki yang kuliah di Jakarta. Kakak ED juga tidak pernah serius menanggapi perilaku ED yang bersifat kemayu. Malahan kakak ED mendekung sifat kemayu ED.

"Saya sih bilang iya aja, yang penting orang tuaku bisa melihat saya berubah. Yah saya bilang aja begitu."

Faktor keempat adalah faktor sosial. Konsep diri terbentuk karena adanya interaksi ED dengan orang-orang disekitarnya. Sejak kecil ED sering bermain, tidur, dan kemana-mana dengan teman perempuan. Waktu SMA, subjek meiliki genk yang berjumlah 12 orang, dan di dalam genk tersebut hanya ED yang laki-laki. ED tidak peduli terhadap pendapat lingkungan sekitar padanya. ED 
menganggap bahwa hidup yang dia jalani adalah hak miliknya seutuhnya. Apapun yang orang lain katakan, ED tidak peduli.

"Kalo saya sih teman dekat ku itu paling dalam satu kelas itu cewek kayak dulu kan waktu di SMK 8, saya punya genk 12 orang dan Cuma saya yang cowok."

Berdasarkan pemaparan yang diungkapkan tersebut, faktor-faktor penyebab yang pada akhirnya mempengaruhi konsep diri yang dimiliki oleh ED adalah cenderung megarah ke hal positif. Penilaian yang positif terhadap keadaan seseorang, baik dari diri sendiri maupun dari orang lain sangat membantu perkembangan konsep diri kearah yang positif (Rahmaningsih \& Martani, 2014).

\section{PENUTUP}

Waria adalah akronim dari wanita pria. Dalam Kamus Besar Bahasa Indonesia, memiliki arti "pria yang bertingkah laku dan atau memiliki perasaan seperti wanita". Subek menerima dirinya apa adanya begitupun juga orang lain. Apabila ada orang lain yang mampu menerima dirinya apa adanya maka dia sangat menghargai hal tersebut. Konsep diri bukan merupakan faktor yang dibawa sejak lahir, tetapi merupakan faktor yang dipelajari dan terbentuk dari pengalaman individu dalam hubungannya dengan orang lain. Dalam berinteraksi setiap individu akan menerima tanggapantanggapan yang diberikan dan dijadikan cermin bagi individu untuk menilai dan memandang dirinya sendiri (Pudjiyogyanti, 1985).

Konsep diri merupakan pandangan atas diri sendiri, pengenalan diri sendiri dan pemahaman diri sendiri. Pandangan ini meliputi karakteristik kepribadian dari individu, nilai-nilai kehidupan, prinsip hidup, moralitas, pengalaman dan interaksi individu dengan lingkungan sekitarnya. Konsep diri terdiri dari bagaimana individu melihat diri sendiri sebagai pribadi, bagaimana individu dapat merasakan apa yang ada didalam dirinya, bagaimana individu menginginkan dirinya sendiri menjadi individu yang ideal dan bagaimana gambaran serta pandangan orang lain tentang diri individu itu sendiri.

Ada tiga hal utama yang menyebabkan perubahan dalam konsep diri lelaki menjadi waria, yaitu perlakuan dan pola asuh orangtua, peneriman positif dari lingkungan sekitar dan kekerasan seksual yang pernah dialami.

Konsep diri pada waria adalah mereka mempersepsikan bahwa menjadi waria sebagai takdir dari Sang Pencipta. Waria menganggap bahwa Tuhanlah yang menjadikan pribadinya adalah seorang perempuan, sementara fisiknya berbentuk laki-laki. Dua dari subjek yang 
diwawancarai menjadikan di mereka tidak berusaha kembali ke fitrahnya sebagai laki-laki yang seutuhnya.

Waria dalam kehidupan sehari-hari memerankan peran ganda. Dalam beberapa urusan mereka menempatkan diri mereka sebagai seorang perempuan, namun dalam keterkaitannya dengan Tuhan dan agama mereka akan menjadi laki-laki seutuhnya. Misalnya shalat, mereka masih menggunakan sarung karena urusan dengan tuhan bukan hal yang harus dipermainkan.

\section{DAFTAR PUSTAKA}

Alfaris, M.R. (2018). Eksistensi Diri Waria dalam Kehidupan Sosial di Tengah Masyarakat Kota (Fenomenologi Tentang Eksistensi Diri Waria Urbanisasi di Kota Malang). Widya Yuridika Jurnal Hukum, Vol.1, No.1, 97-114.

Barmawi \& Silmi, M. (2016). Identifikasi Penyebab Transgender pada Waria di Banda Aceh. Jurnal Psikoislamedia, Vol.1, No.2, 372384.

Damarhadi, S., Mujidin \& Prabawanti. (2020). Gambaran Konsep Diri pada SMA Ditinjau Berdasarkan Jenis Kelamin. Psikostudia: Jurnal Psikologi, Vol.9, No.3, 251-259.
Faidah, M. \& Abdullah, H. (2013). Religiusitas dan Konsep Diri Kaum Waria. Jurnal Studi Gender Indonesia, Vol.4, No.1, 1-14.

Ibrahim, Salman, D., \& Suardi. (2015). Pembentukan Identitas Kaum Waria Kecamatan Bulukumpa. Jurnal Equilibrium Pendidikan Sosiologi, Vol.3, No.1, 47-56.

Latiefah, U. (2013). Pesantren Waria dan Konstruksi Identitas. Jurnal Pemikiran Sosiologi, Vol.2, No.1, 87-96.

Noor, W.K., \& Qomariyah, U. (2019). Hierarki Kebutuhan sebaga Dasar Refleksi Diri Tokoh dalam Novel Pesantren Impian. Jurnal Sastra Indonesia, Vol.8, No.2, 103-110.

Prasetya, B., Usaman, M. \& Syamsi, M.F. (2020). Makna Religiusitas Bagi Kaum Waria. Analsis : Jurnal Studi Keislaman, Vol.20, No.1,95-108.

Rahmaningsih, N.D. \& Martani, W. (2014). Dinamika Konsep Diri pada Remaja Perempuan Pembaca Teenlit. Jurnal Psikologi, Vol.41, No.2, 179-189.

Ruhghea, S., Mirza \& Rachmatan, R. (2014). Studi Kualitatif Kepuasan Hidup Pria Transgender (Waria) di Banda Aceh. Jurnal Psikologi Undip, Vol.13, No.1, 11-20. 
Saputri, M.E. \& Moordiningsih. (2016). Pembentukan Konsep Diri Remaja pada Keluarga Jawa yang Beragama Islam. Jurnal Ilmiah Psikologi Terapan, Vol.4, No.2, 261-268.
Widiarti, P.W. (2017). Konsep Diri SelfConcept) dan Komunikasi Interpersonal dalam Pendampingan pada Siswa SMP se-Kota Yogyakarta. Informasi: Kajian Ilmu Komunikasi, Vol.47, No.1, 135-148. 